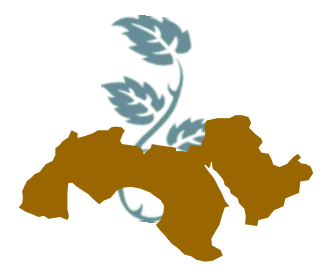

\title{
IN VITRO PROPAGATION OF KORONAKI AND CORATINA OLIVE CVS.
}

\author{
$[132]$ \\ Rehab N. Mostofa ${ }^{1}$, Abu Rawash ${ }^{2}$ M.A., Elwakeel ${ }^{2}$ H.F. and Vergini F. Noaman ${ }^{1}$ \\ 1- Olive and Smei Arid Zone Fruits, Dept., Horticulture Research Inistitute, Giza, Egypt \\ 2- Horticulture Dept. Fac. of Agric. Ain Shams Univ., P.O. Box 68 Hadayek Shoubra 11241, \\ Cairo, Egypt
}

Keywords: Olive; Coratina cv.; Koronaki cv.; In vitro propagation; Sterilization; Multiplication; Rooting; Acclamization

\section{ABSTRACT}

Experiments carried out through 2016 revealed that a proper protocol for the in vitro propagation of Koronaki and Coratina olive cvs. as follows : Sterilization of stem node explants was carried out successfuly with copper sulphate at $50 \mathrm{mg} / \mathrm{l}$ for Koronaki cv. And Ampicillin at $150 \mathrm{mg} / \mathrm{l}$ for Coratina cv. both cultured on Olive medium.Multiplication on MS medium enriched with BAP at $1.5 \mathrm{mg} / \mathrm{l}$ for both crs.

Rooting of Koronaki on half sterngth OM medium enriched with IBA at $0.5 \mathrm{mg} / \mathrm{l}$ and Coratina on half sterngth MS medium enriched with NAA at $0.1 \mathrm{mg} / \mathrm{l}$.

Acclimization of Koronaki plantlets derived from half strength $\mathrm{OM}$ rooting medium and acclimatized on peat : sand (1:1) and Coratina plantlets derived from MS rooting medium and acclimatized on peat :sand : vermiculite $(1: 1: 1)$.

\section{INTRODUCTION}

Olive (Olea europaea L.) is one of the most important fruit tree crop specially in of the Mediterranean sea countries. Olive is usually propagated by the conventional methods which are inefficient and have a limited success for some cultivars (such as Kalamata, Dolcie, Coratina and Koronaki). Propagation through seed is not desirable due to segregation and a long period of juvenility. Consequently, for most olive cultivars, micropropagation is more convenient than traditional propagation (Rugini et al 2001).
Besides the mineral formulation, growth regulators are also one of the most important components of the in vitro culture media. Since the pioneering work of OM medium (Rugini, 1984) is considered up-to-now as the most suitable one for olive micropropagation, but they also proved not to be effective for all cultivars (Katerina et al 2002) and (Peixe et al 2007). Acclimization media is one of the most important factor ( İsfendiyaroğlu et al 2007)

Micropropagation is a powerful tool for the quick production of genetically homogenous plants, since it enables rapid propagation and hastens the ability of new cultivars.

In fact, several studies have been conducted with the aim of developing alternative micropropagation methods that can help to overcome the limitations associated with the traditional techniques currently used for the propagation of olive trees (Peixe et al 2007and Roussos et al 2002).

In vitro propagation of olive is still limited, due to poor growth, poor lateral bud outgrowth, variable rooting ability and acclamization of the plantlets. Another problem encountered is that of intraspecific variation in tissue culture responses between different cultivars (Cozza et al 1997).

The present study was undertaken in order to develop a protocol for the rapid propagation of Koronaki and Coratina' olive cvs. through in vitro technique

\section{MATERIALS AND METHODS}

The present study was carried out throught the spring of 2016 in order to find a protocol for the in vitro propagation of two hard to root olive cvs. Namely "Koronaki and Coratina". 
However the subsequent procedures which practized here were as follow:

\section{- Explant type}

Cuttings of $15-20 \mathrm{~cm}$ length from middle parts of one-year shoots were collected from mature Koronaki and Coratina' olive trees of about 15 years old grown in Horticulture Research Institute farm. Giza, Egypt.

Stem node explants were taken from such cuttings then they were washed with tap water for an hour, and soaked in Sodium hypochlorite $(\mathrm{NaOCl})$ $10 \%$ for $7 \mathrm{~m}$ and Mercury chloride $(\mathrm{HgCl} 2) 50 \mathrm{mg} / \mathrm{l}$ for $7 \mathrm{~m}$. After which they were soaked three times with sterile water (10min for each) then following sterilization treatments were applied.

\section{- Explant Sterelization}

Four sterilization treatments were teasted i.e. control (distiled water), ampicillin $150 \mathrm{mg} / \mathrm{l}$, copper sulphate at $50 \mathrm{mg} / \mathrm{l}$, copper sulphate $100 \mathrm{mg} / \mathrm{l}$.

\section{- Multiplication Media}

Two nuttional media i.e. Murashige and Skoog (Murashige and Skoog, 1962) and Olive medium (Ruggini, 1984) were tried where each one was enriched with one of the six following cytokinin treatments, (BAP 0.5,1 and 1.5mg/l) Kin (0.5, 1and $1.5 \mathrm{mg} / \mathrm{l})$ besied the control.

\section{- Rooting Media}

The same nutrition media applied in the multiplication stage were used here but half strength and enriched with one of the following six auxin treatments (IBA $0.1,0.3$ and $0,5 \mathrm{mg} / \mathrm{l})$, NAA $(0.1$, 0.3 and $0.5 \mathrm{mg} / \mathrm{l}$ ) besied the control.

\section{- Acclimataziation Media}

The successful plantlets derived from the rooting media were transferred instantly to different acclimatization media namely peat moss:sand $(1 ; 1)$ and peat moss:sand :vermiculite $(1: 1: 1)$ and absorved for two months at outdoor condition in a mist unit in a glasshouse (Rostami and Shahsavar, 2012).

\section{Incubation Conditions}

In each of three stages Estaplishment, Multiplication and Rooting explants were subcultured on fresh medium supplemented with the same concentrations of cytokinins, auxins and incubated in growth chamber at $22 \pm 1^{\circ} \mathrm{C}$, with a photoperiod of $16 \mathrm{~h}$ and a light intensity of 3000 lux (Katerina et al 2002) and adjusted $\mathrm{pH}$ media with $\mathrm{HCl}$ and $\mathrm{NaOH}$ to $5.8 \mathrm{pH}$ before autoclaving.

The experiment was factorial comprised of 3 factors i.e. cultivars, media, and treatments .Where each treatment represented by 4 replicates each one had 4 jars each contains 3explants.

Rooted plantlets were then transferred to a growth-cabinet with the same temperature, photoperiod and light intensity, but with progressive decreasing air humidity (HR) from 100 to $65 \%$. Acclimated plants were then transferred to a greenhouse.

All data parameters studied were analyzed as Randomized Complete Blocks Design in factorial arrangement with three replications. All data were subjected to statistical analysis as described by ( Snedecor and Cochran 1989). Mean separation were carried out using Duncan's multiple range test (Duncan, 1955).

\section{RESULTS AND DISCUSSION}

Data present in Table (1) reveals the effect of different sterilization materials on survival \% of Koronaki and Coratina explants cultured on MS and OM media in spring of 2016.

Results indicated that copper sulphate at 50 $\mathrm{mg} / \mathrm{l}$ gained the significantly greteest survival \% regardless of of two factors (cultivars and media). On the other hand, Koronaki cv. Showed significantly higher survival \% than Coratina cv. irrespective to media and treat factors.

However, OM medium surpassed significantly than MS one in survival \%, regardless of cultivars and treatments.

Regarding of the interation between the three studied factors ( treatments, cvs. and media) it is apparent that Koronaki expanta sterilized with copper sulphate at $50 \mathrm{mg} / \mathrm{l}$ and cultured on OM medium achieved the highest survival \% .(60\%) Such results are in approval with the ( Hassan et al 2016)

In Table (2) one can notice that different studied cytokinins significantly induced shoot formation on studied olive cvs. than control without significant difference among them. 
Table 1. Effect of Different Sterilization Materials on Survival (\%) of Koronaki and Coratina explants cultured on MS and OM media in spring 2016

\begin{tabular}{|c|c|c|c|c|c|}
\hline & \multicolumn{2}{|c|}{ Koronaki } & \multicolumn{2}{|c|}{ Coratina } & \multirow{2}{*}{$\begin{array}{c}\text { Treatments } \\
\text { Mean }\end{array}$} \\
\hline & M.S & OM & M.S & OM & \\
\hline $\begin{array}{l}\text { Control } \\
\text { Ampicillin } 150 \mathrm{mg} / \mathrm{L} \\
\text { Copper Sulphate at } 50 \mathrm{mg} / \mathrm{L} \\
\text { Copper Sulphate at } 100 \mathrm{mg} / \mathrm{L}\end{array}$ & $\begin{array}{l}40.00 \mathrm{~d} \\
40.00 \mathrm{~d} \\
40.00 \mathrm{~d} \\
60.00 \mathrm{a}\end{array}$ & $\begin{array}{l}20.00 \mathrm{f} \\
43.33 \mathrm{c} \\
60.00 \mathrm{a} \\
30.00 \mathrm{e}\end{array}$ & $\begin{array}{l}00.00 \mathrm{~h} \\
20.00 \mathrm{f} \\
50.00 \mathrm{~b} \\
30.00 \mathrm{e}\end{array}$ & $\begin{array}{l}10.00 \mathrm{~g} \\
60.00 \mathrm{a} \\
50.00 \mathrm{~b} \\
50.00 \mathrm{~b}\end{array}$ & $\begin{array}{l}17.50 \mathrm{C} \\
40.83 \mathrm{~B} \\
50.00 \mathrm{~A} \\
42.50 \mathrm{~B}\end{array}$ \\
\hline Cv. Mean & \multicolumn{2}{|l|}{$41.67 \mathrm{~A}^{-}$} & \multicolumn{2}{|l|}{$33.75 \mathrm{~B}^{-}$} & \\
\hline Media Mean & \multicolumn{2}{|l|}{$35.00 \mathrm{~B}^{+}$} & \multicolumn{2}{|l|}{$40.42 \mathrm{~A}^{+}$} & \\
\hline
\end{tabular}

Means having the same letter (s) in each row, column or interaction are insignifently different at $5 \%$ level in each table

Table 2. Effect of Cytokinens, cultivars and media type on number of Shoot/ explant in the $1^{\text {st }}$ subculture of multiplication stage in spring 2016

\begin{tabular}{|c|c|c|c|c|c|}
\hline & \multicolumn{2}{|c|}{ Koronaki } & \multicolumn{2}{|c|}{ Coratina } & \multirow{2}{*}{$\begin{array}{l}\text { Treatments } \\
\text { Mean }\end{array}$} \\
\hline & M.S & OM & M.S & OM & \\
\hline Control & $0.00 \mathrm{c}$ & $0.00 \mathrm{c}$ & $0.00 \mathrm{c}$ & $0.00 \mathrm{c}$ & $0.00 \mathrm{~B}$ \\
\hline BAP $0.5 \mathrm{mg} / \mathrm{L}$ & $1.66 a b$ & $1.33 a b$ & $1.66 a b$ & $2.00 a b$ & $1.66 \mathrm{~A}$ \\
\hline BAP $1.0 \mathrm{mg} / \mathrm{L}$ & $1.33 a b$ & $1.33 a b$ & $1.66 a b$ & $1.66 a b$ & $1.50 \mathrm{~A}$ \\
\hline BAP $1.5 \mathrm{mg} / \mathrm{L}$ & $2.00 a b$ & $1.33 a b$ & $2.33 \mathrm{a}$ & $2.00 \mathrm{ab}$ & $1.91 \mathrm{~A}$ \\
\hline kin $0.5 \mathrm{mg} / \mathrm{L}$ & $1.00 \mathrm{bc}$ & $1.00 \mathrm{bc}$ & $1.66 \mathrm{ab}$ & $1.66 \mathrm{ab}$ & $1.33 \mathrm{~A}$ \\
\hline kin $1.0 \mathrm{mg} / \mathrm{L}$ & $2.00 \mathrm{ab}$ & $1.33 a b$ & $2.00 \mathrm{ab}$ & $1.33 a b$ & $1.66 \mathrm{~A}$ \\
\hline kin $1.5 \mathrm{mg} / \mathrm{L}$ & $1.66 \mathrm{ab}$ & $2.33 \mathrm{a}$ & $1.33 a b$ & $1.33 a b$ & $1.66 \mathrm{~A}$ \\
\hline Cv. Mean & \multicolumn{2}{|l|}{$1.452 \mathrm{~A}^{-}$} & \multicolumn{2}{|l|}{$1.333 \mathrm{~A}^{-}$} & \\
\hline Media Mean & \multicolumn{2}{|l|}{$1.310 \mathrm{~A}^{+}$} & \multicolumn{2}{|l|}{$1.476 \mathrm{~A}^{+}$} & \\
\hline
\end{tabular}

Means having the same letter (s) in each row, column or interaction are insignifently different at $5 \%$ level in each table

In addition, the two studied cvs. as well as the two practized multiplication media failed to differ significantly.

However, Koronaki cv. Cultured on OM medium enriched with Kin at $1.5 \mathrm{mg} / \mathrm{l}$ as well Coratina explants cultured on MS medium enriched with BAP $1.5 \mathrm{mg} / /$ showed the greatest number of shoots /explants (2.33). Such results are in accordance with the finding of (Roussos and Pontikis, 2002) and (Katerina et al 2002).

As shown in Table (3) BAP at 1 and $1.5 \mathrm{mg} / \mathrm{l}$ gave the tallest shoots without significant difference than BAP $0.5 \mathrm{~g} / \mathrm{l}$ regardless of other studied factors.

In addition koronaki cv was better than coratina one irrespective to other studied factors.

Meanwhile, no significant difference was detected between both studied multiplication media.
Regarding the interaction between the three studied factors, one can observe that Koronaki explants cultured on Ms medium enriched with BAP at $0.5 \mathrm{mg} / \mathrm{l}$ exhibited the tallest shoots $(5.86 \mathrm{~cm})$.

As the effect of cytokinins on the number of leaves /explant, Table (4) exhibited that BAP at $1.5 \mathrm{mg} / \mathrm{L}$ gained the significantly greatest number regardless of other studied factors.

On the other hand, both cvs. And media variables failed to affect such parameter irrespective to cytokinin factor.

However, Koronaki explants cultured on MS medium supplemented by BAP $1.5 \mathrm{mg} / \mathrm{L}$ gave the greatest number of leaves /explants (23.43).

The obtained results are in agreement with the finding of (Ansar et al 2009 b); Hassan et al 2016). On the contrary, the present results differ than the finding of (Manisha et al 2014). 
Table 3. Effect of Cytokinens, cultivars and media type on mean of Shoot length $(\mathrm{cm})$ in the $1^{\text {st }}$ subculture of multiplication stage in spring 2016

\begin{tabular}{|c|c|c|c|c|c|}
\hline & \multicolumn{2}{|c|}{ Koronaki } & \multicolumn{2}{|c|}{ Coratina } & \multirow{2}{*}{$\begin{array}{c}\text { Treatments } \\
\text { Mean }\end{array}$} \\
\hline & M.S & OM & M.S & OM & \\
\hline Control & $2.45 \mathrm{i}$ & $2.43 \mathrm{i}$ & $2.16 \mathrm{i}$ & $2.69 \mathrm{i}$ & $2.43 \mathrm{C}$ \\
\hline BAP $0.5 \mathrm{mg} / \mathrm{L}$ & $5.86 a$ & 3.92 e-h & $4.81 \mathrm{~b}-\mathrm{d}$ & $3.49 \mathrm{~h}$ & 4.52 AB \\
\hline BAP $1.0 \mathrm{mg} / \mathrm{L}$ & $5.46 a b$ & $4.70 \mathrm{~b}-\mathrm{e}$ & $5.33 a-c$ & $4.45 \mathrm{~d}-\mathrm{g}$ & $4.98 \mathrm{~A}$ \\
\hline BAP $1.5 \mathrm{mg} / \mathrm{L}$ & 4.92 b-d & $4.13 d-h$ & $5.45 a b$ & $3.44 \mathrm{~h}$ & 4.48 AB \\
\hline kin $0.5 \mathrm{mg} / \mathrm{L}$ & $3.70 \mathrm{gh}$ & $3.48 \mathrm{~h}$ & $4.71 \mathrm{~b}-\mathrm{e}$ & 3.95 e-h & $3.96 \mathrm{~B}$ \\
\hline kin $1.0 \mathrm{mg} / \mathrm{L}$ & $4.48 \mathrm{~d}-\mathrm{g}$ & $3.55 \mathrm{~h}$ & $4.60 \mathrm{c}-\mathrm{f}$ & $3.74 \mathrm{gh}$ & $4.09 \mathrm{~B}$ \\
\hline kin $1.5 \mathrm{mg} / \mathrm{L}$ & $3.51 \mathrm{~h}$ & $3.84 \mathrm{f}-\mathrm{h}$ & $4.58 c-f$ & $4.21 \mathrm{~d}-\mathrm{h}$ & $4.03 \mathrm{~B}$ \\
\hline Cv. Mean & \multicolumn{2}{|l|}{$4.433 \mathrm{~A}^{-}$} & \multicolumn{2}{|l|}{$3.718 \mathrm{~B}^{-}$} & \\
\hline Media Mean & \multicolumn{2}{|l|}{$4.033 \mathrm{~A}^{+}$} & \multicolumn{2}{|l|}{$4.118 \mathrm{~A}^{+}$} & \\
\hline
\end{tabular}

Means having the same letter (s) in each row, column or interaction are insignifently different at $5 \%$ level in each Table

Table 4. Effect of Cytokinens, cultivars and media type on number of leaves/ explant in the $1^{\text {st }}$ subculture of multiplication stage in 2016

\begin{tabular}{|c|c|c|c|c|c|}
\hline & \multicolumn{2}{|c|}{ Koronaki } & \multicolumn{2}{|c|}{ Coratina } & \multirow{2}{*}{$\begin{array}{c}\text { Treatments } \\
\text { Mean }\end{array}$} \\
\hline & M.S & OM & M.S & OM & \\
\hline $\begin{array}{l}\text { Control } \\
\text { BAP } 0.5 \mathrm{mg} / \mathrm{L} \\
\text { BAP } 1.0 \mathrm{mg} / \mathrm{L} \\
\text { BAP } 1.5 \mathrm{mg} / \mathrm{L} \\
\text { kin } 0.5 \mathrm{mg} / \mathrm{L} \\
\text { kin } 1.0 \mathrm{mg} / \mathrm{L} \\
\text { kin } 1.5 \mathrm{mg} / \mathrm{L}\end{array}$ & $\begin{array}{l}6.00 \mathrm{o} \\
20.03 \mathrm{bc} \\
16.24 \mathrm{f}-\mathrm{i} \\
23.43 \mathrm{a} \\
11.60 \mathrm{n} \\
13.40 \mathrm{k}-\mathrm{n} \\
13.73 \mathrm{j}-\mathrm{n}\end{array}$ & $\begin{array}{l}4.66 \mathrm{o} \\
14.23 \mathrm{i}-\mathrm{m} \\
20.50 \mathrm{~b} \\
17.57 \mathrm{~d}-\mathrm{g} \\
13.00 \mathrm{I-n} \\
14.03 \mathrm{i}-\mathrm{m} \\
15.87 \mathrm{~g}-\mathrm{j}\end{array}$ & $\begin{array}{l}5.66 \mathrm{o} \\
15.53 \mathrm{~g}-\mathrm{k} \\
16.75 \mathrm{e}-\mathrm{h} \\
18.88 \mathrm{~b}-\mathrm{e} \\
18.09 \mathrm{c}-\mathrm{f} \\
13.84 \mathrm{j}-\mathrm{n} \\
12.49 \mathrm{mn}\end{array}$ & $\begin{array}{l}5.330 \\
13.60 \mathrm{j}-\mathrm{I} \\
14.87 \mathrm{~h}-\mathrm{I} \\
18.43 \mathrm{~b}-\mathrm{e} \\
19.45 \mathrm{~b}-\mathrm{d} \\
14.72 \mathrm{~h}-\mathrm{m} \\
15.83 \mathrm{~g}-\mathrm{j}\end{array}$ & $\begin{array}{l}5.41 \mathrm{D} \\
15.85 \mathrm{BC} \\
17.09 \mathrm{~B} \\
19.58 \mathrm{~A} \\
15.53 \mathrm{BC} \\
14.00 \mathrm{C} \\
14.48 \mathrm{C}\end{array}$ \\
\hline Cv. Mean & \multicolumn{2}{|l|}{$14.69 \mathrm{~A}^{-}$} & \multicolumn{2}{|l|}{$14.44 \mathrm{~A}^{-}$} & \\
\hline Media Mean & \multicolumn{2}{|l|}{$14.59 \mathrm{~A}^{+}$} & \multicolumn{2}{|l|}{$14.53 \mathrm{~A}^{+}$} & \\
\hline
\end{tabular}

Means having the same letter (s) in each row, column or interaction are insignifently different at $5 \%$ level in each Table

The beneficial effect of cytokinins in improving and hastening the number of shoots and their length as well as number of leaves per explant may be due to their chemical structure which contain nitrogenous bases especially adenine which considered as a component of nucleic acids which in turn play an important role of breaking apical dominance of the terminal bud and inducing branching.

Regarding the effect of auxins on rooting \%, number of roots / explant and root length, Tables (5, 6 and 7 ) indicated that both IBA and NAA at any concentration significantly increased the three studied parameters than the control regardless of the other two factors.

On the contrary, both cvs. and rooting media failed to affect the three considered parameters irrespective to auxin treatments. As far the effect of the interaction between the auxin treatment, cvs. and rooting media, it is apparent that Koronaki cv. cultured on half-strength OM medium enriched with $0.5 \mathrm{mg}$ IBA/L as well as Coratina $\mathrm{cv}$. cultured on half-strength MS medium supplemented with 0.1 $\mathrm{mg} / \mathrm{L} \mathrm{NAA}$ achieved the significantly highest rooting \% (80.0).

Meanwhile, Koronaki explants grown on OM medium enriched by $0.1 \mathrm{mg} / \mathrm{L}$ IBA gained the greatest number of roots / explants. (7.33). On the other hand, Koronaki explant cultured on MS medium plus $0.3 \mathrm{mg} / \mathrm{L}$ NAA showed the tallest root length $(18.67 \mathrm{~cm})$.Such results are in accordance with those found by (Binet et al 2002), (Mencuccini 2002) and (Ali et al 2009). Whereas, they differ than the results of (Katerina et al 2002), (Ansar et al 2009a) and (Manisha et al 2014). 
Table 5. Effect of different auxin concentrations on rooting percentage of "Koronaki " and "Coratina" cvs shoots after 5 weeks on rooting medium 2016

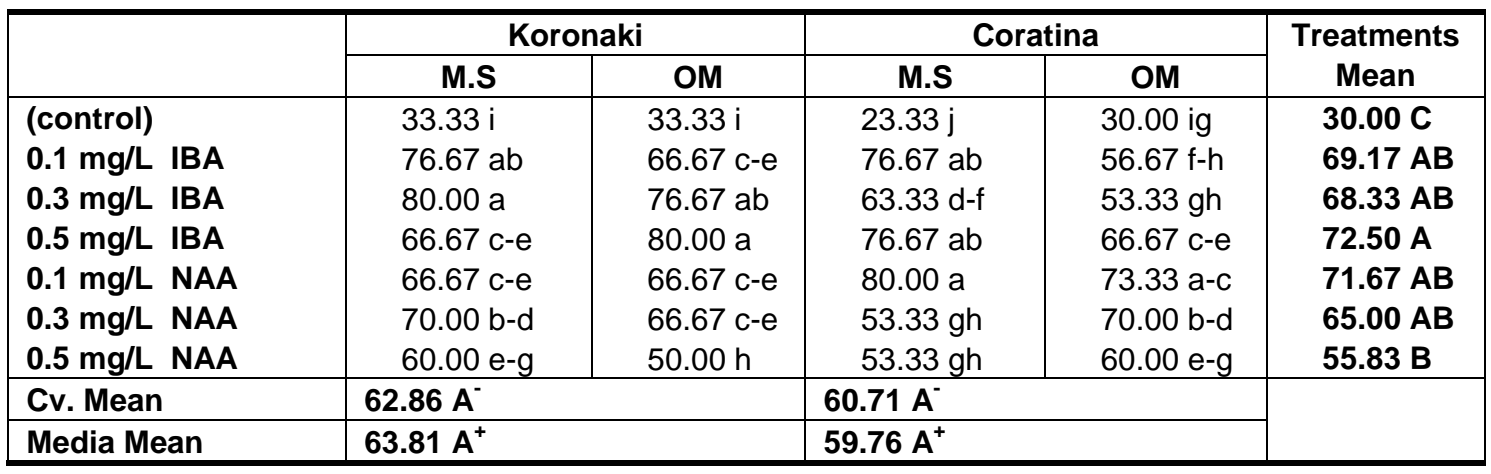

Means having the same letter (s) in each row, column or interaction are insignifently different at $5 \%$ level in each Table

Table 6. Effect of different auxin concentrations on number of root/explant of "Koronaki " and "Coratina" cvs shoots after 5 weeks on rooting medium 2016

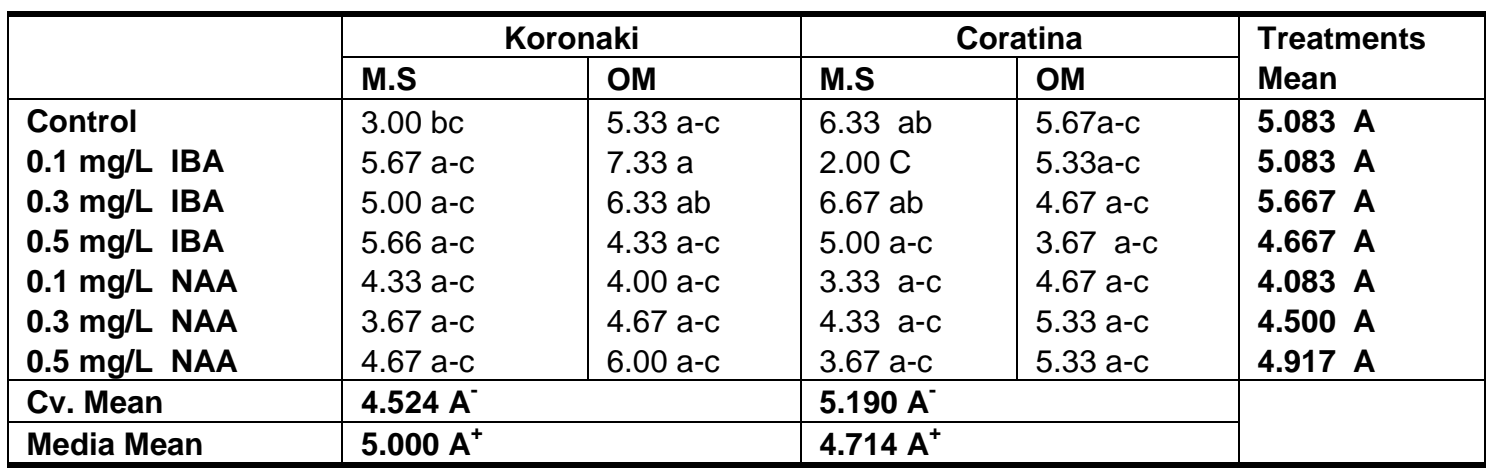

Means having the same letter (s) in each row, column or interaction are insignifently different at $5 \%$ level in each Table

Table 7. Effect of different auxin concentrations on mean of root length $(\mathrm{cm})$ of "Koronaki" and "Coratina" cvs shoots after 5 weeks on rooting medium 2016

\begin{tabular}{|c|c|c|c|c|c|}
\hline & \multicolumn{2}{|c|}{ Koronaki } & \multicolumn{2}{|c|}{ Coratina } & \multirow{2}{*}{$\begin{array}{l}\text { Treatments } \\
\text { Mean }\end{array}$} \\
\hline & M.S & OM & M.S & OM & \\
\hline (control) & 2.17 & $3.33 \mathrm{~h}-\mathrm{j}$ & $2.50 \mathrm{ij}$ & $3.33 \mathrm{~h}-\mathrm{j}$ & $2.83 \mathrm{~B}$ \\
\hline $0.1 \mathrm{mg} / \mathrm{L}$ IBA & $5.00 \mathrm{e}-\mathrm{j}$ & $11.50 \mathrm{bc}$ & $9.33 \mathrm{~b}-\mathrm{h}$ & $9.00 \mathrm{~b}-\mathrm{h}$ & $8.71 \mathrm{~A}$ \\
\hline $0.3 \mathrm{mg} / \mathrm{L}$ IBA & $7.17 \quad c-j$ & $11.33 \mathrm{~b}-\mathrm{d}$ & $8.33 \mathrm{~b}-\mathrm{i}$ & $8.67 b-h$ & $8.88 \mathrm{~A}$ \\
\hline $0.5 \mathrm{mg} / \mathrm{L}$ IBA & $4.33 \mathrm{f}-\mathrm{j}$ & $7.17 \quad c-j$ & 10.67 b-e & $9.50 \mathrm{~b}-\mathrm{g}$ & 7.92 AB \\
\hline $0.1 \mathrm{mg} / \mathrm{L} \quad \mathrm{NAA}$ & $10.80 \mathrm{~b}-\mathrm{e}$ & $6.17 \mathrm{c}-\mathrm{j}$ & $6.17 \mathrm{c}-\mathrm{j}$ & $10.00 \mathrm{~b}-\mathrm{g}$ & 8.28 AB \\
\hline $0.3 \mathrm{mg} / \mathrm{L}$ NAA & $18.67 \mathrm{a}$ & 10.17 b-f & $4.00 \quad g-j$ & $8.33 \mathrm{~b}-\mathrm{i}$ & 10.29 A \\
\hline $0.5 \mathrm{mg} / \mathrm{L}$ NAA & $14.17 \mathrm{ab}$ & 4.83 e-j & $6.50 \mathrm{c}-\mathrm{j}$ & $5.33 \mathrm{~d}-\mathrm{j}$ & 7.71 AB \\
\hline Cv. Mean & \multicolumn{2}{|l|}{$7.843 \mathrm{~A}^{-}$} & \multicolumn{2}{|l|}{$7.762 \mathrm{~A}^{-}$} & \\
\hline Media Mean & \multicolumn{2}{|l|}{$8.343 \mathrm{~A}^{+}$} & \multicolumn{2}{|l|}{$7.262 \mathrm{~A}^{+}$} & \\
\hline
\end{tabular}

Means having the same letter (s) in each row, column or interaction are insignifently different at $5 \%$ level in each Table 
The mode of action of auxin as mentioned by previous investigations as increasing the elasticity and plasticity of cell wall by activating the cellulose and pectinase and other hydrolytic enzymes, as well as inducing cell division and formation of adventitious roots on stem and leaves tissues.
As for the achieved experiment Table (8) illustrates that Koronaki plantlets derived from OM rooting medium and transplanted into peat moss: sand $(1: 1)$ showed significantly higher survival \% (66.67) opposite to Coratina plantles derived from the same rooting medium and transplanted into any acclimatization medium (20\%).

Table 8. Effect of acclimatization medium on survival (\%) of "Koronaki "and "Coratina" plantlets developed on MS and OM rooting media after (2 months) acclimatization

\begin{tabular}{|c|c|c|c|c|c|}
\hline & \multicolumn{2}{|c|}{ Koronaki } & \multicolumn{2}{|c|}{ Coratina } & \multirow{2}{*}{$\begin{array}{c}\text { Acclimatization } \\
\text { Mean }\end{array}$} \\
\hline & M.S & OM & M.S & OM & \\
\hline Peat moss: sand (1:1) & $60.00 \mathrm{~b}$ & $66.67 \mathrm{a}$ & $33.33 \mathrm{e}$ & $20.00 \mathrm{f}$ & $44.44 \mathrm{~A}$ \\
\hline $\begin{array}{l}\text { Peat moss: sand : vermiculite } \\
(1: 1: 1)\end{array}$ & $31.10 \mathrm{e}$ & $40.00 \mathrm{~d}$ & $53.33 \mathrm{c}$ & $20.00 \mathrm{f}$ & $36.67 \mathrm{~B}$ \\
\hline Cv. Mean & \multicolumn{2}{|l|}{$49.44 \mathrm{~A}^{-}$} & \multicolumn{2}{|c|}{$31.67 \mathrm{~B}^{-}$} & \\
\hline Rooting Media Mean & \multicolumn{2}{|l|}{$45.00 \mathrm{~A}^{+}$} & \multicolumn{2}{|c|}{$36.11 \mathrm{~B}^{+}$} & \\
\hline
\end{tabular}

Means having the same letter (s) in each row, column or interaction are insignifently different at $5 \%$ level in each Table

Regarding the effect of acclimatization medium on shoot length of the developed plantlets, Table (9) showed that no significant differences were detected between the three studied factors.
But in regarding the interaction between these variables, one can notice that Coratina plantlets derived from MS rooting medium and transplanted into any considered acclimatization medium gained the tallest shoots $(13.67$ and $15.00 \mathrm{~cm}$.

Table 9. Effect of acclimatization medium on shoot length $(\mathrm{cm})$ of "Koronaki" and "Coratina" plantlets developed on MS and OM rooting media after (2 months) acclimatization

\begin{tabular}{|c|c|c|c|c|c|}
\hline & \multicolumn{2}{|c|}{ Koronaki } & \multicolumn{2}{|c|}{ Coratina } & \multirow{2}{*}{$\begin{array}{c}\text { Acclimatization } \\
\text { Mean }\end{array}$} \\
\hline & M.S & OM & M.S & OM & \\
\hline Peat moss: sand (1:1) & $13.00 \mathrm{ab}$ & $12.33 \mathrm{ab}$ & $13.67 \mathrm{a}$ & $12.67 \mathrm{ab}$ & $12.92 \mathrm{~A}$ \\
\hline $\begin{array}{l}\text { Peat moss: sand :vermiculite } \\
(1: 1: 1)\end{array}$ & $8.33 c$ & $10.00 \mathrm{bc}$ & $15.00 \mathrm{a}$ & $12.00 \mathrm{ab}$ & $11.33 \mathrm{~A}$ \\
\hline Cv. Mean & \multicolumn{2}{|l|}{$10.91 \mathrm{~A}^{-}$} & \multicolumn{2}{|l|}{$13.33 \mathrm{~A}^{-}$} & \\
\hline Rooting Media Mean & \multicolumn{2}{|l|}{$12.50 \mathrm{~A}^{+}$} & \multicolumn{2}{|l|}{$11.75 \mathrm{~A}^{+}$} & \\
\hline
\end{tabular}

Means having the same letter (s) in each row, column or interaction are insignificantly different at $5 \%$ level in each Table

\section{CONCLUSION AND RECOMMENDATION}

The main target of the present research work is developing protocols for in vitro propagating of two hard to root olive cvs. Namely, Koronaki and Coratina, where such cvs. are too famous as oil cvs. where fruit oil \% reaches about $24 \%$ as fresh weight basis but unfortunately they are difficult to be propagated by stem cutting by the use of auxin treatment.
However, the recommended explant type for olive crs. (stem node) was adopted, and different sterilization multiplication, rooting and acclimization methods were tried here finally, such work ended to the proper protocol for the In vitro propagation for each cv. individually as follows.

Koronaki alive cv. sterilization of explants with copper sulphate $50 \mathrm{mg} / \mathrm{l}$. Multiplication on OM medium enriched with Kin 1.5mg/l. Rooting on OM 
medium enriched by IBA at $0.5 \mathrm{mg}$. Acclamization on peat moss: sand $(1: 1)$.

Coratina alive cv. sterilization of explants with ampcellin 150mg/l. Multiplication on MS medium enriched with BAP at $1.5 \mathrm{mg} / \mathrm{l}$. Rooting on MS medium enriched by $0.1 \mathrm{mg} / \mathrm{l}$ NAA. Acclamization on peat moss : sand : vermiculite $(1: 1: 1)$

\section{REFERENCES}

Ansar, A., Touqeer, A., Nadeem, A.A. and Ishfaq A.H. 2009 a. Effect of different concentrations of auxins on in vitro rooting of olive cultivar 'Moraiolo'. Pak. J. Bot., 41(3), 1223-1231.

Ansar, A., Touqeer, A., Nadeem, A.A. and Ishfaq A.H. 2009 b. Effect of Media and Growth Regulators on in-vitro shoot proliferation of olive cultivar 'Moraiolo'. Pak. J. Bot., 41(2), 783795.

Binet, M.N., Lemoine, M.C., Martin, C., Chambon C. and Gianinazzi S. 2007. Micropropagation of olive (Olea europaea L.) and application of mycorrhiza to improve plantlet establishment In Vitro Cell. Dev. Biol., Plant 43, 473-478

Cozza, R., Turco, D., Briccoli Bati, C. and Bitonti, M.B. 1997. Influence of growth medium on mineral composition and leaf histology in micropropagated plantlets of Olea europaea. Plant Cell Tissue Organ Cult 51, 215-223.

Duncan, D.B.1955. Multiple range and multiple F. Tests Biometrics, 11, 1-24

Hassan, S.A.M., Abd Allatif, A.M., Mahfouze Heba A. 2016. Assessment of Genetic Stability of Micropropagated Olive (Olea europaea). J. of PharmTech Research, 9(12), 816-825.

İsfendiyaroğlu, M., Özeker, E. and Başer, S. 2009. Rooting of 'Ayvalik' olive cuttings in different media. Spanish J. Agric. Res., 7(1), 165-172.
Katerina, G., Vasilakakis, M. and Eleftherios, P.E. 2002. In vitro propagation of the Greek olive cultivar 'Chondrolia Chalkidikis' Plant Cell, Tissue and Organ Culture 71, 47-54

Mangal, M., Sharms, D., Sharma, M., and Kumar, S. 2014. In Vitro regeneration in Olive (Olea europaea L. cv, Frontio from nodel segments. Indian J. of Exprimental Biology 5, 912-916.

Mencuccini, M. 2003. Effect of medium Darkening on in vitro rooting capability and rooting seasonality of olive (Olive europaea I.). Cultivars Scientia Horticultre 97,129-139.

Murashige, T. and Skoog, F. 1962. A Revised Medium for Rapid Growth and Bioassays withTobacco Tissue Cultures. Physiologia Plantarum, 15, 473-497.

Peixe, A., Raposo, A., Lourenc, R., Cardoso, O.H.E. and Macedo, E. 2007. Coconut water and BAP successfully replaced zeatin in olive (Olea europaea L.). Micropropagation Scientia Horticulturae 113, 1-7.

Rostami, A.A. and Shahsavar, A. 2012. In vitro micropropagation of olive (Olea europaea L.). Mission" by nodal segments. J. Biol. Environ. Sci., 6, 155-159.

Roussos, P.A. and Pontikis, C.A. 2002. In vitro propagation of olive (Olea europaea L.) cv. Koroneiki. Plant Growth Regulation 37, 295304.

Rugini, E., Biasi, R., Muganum, M., Pannelli G., Aversa, G., Maggini, F., Martelli, G.P., Zamboni, E., Zuccherelli, G. and Barba, M. 2001. L'organizzazione di un modern vivaismo olivicolo alla base della produzione di piante certificate. Frutticoltura 5, 11-24.

Rugini E. 1984. In vitro propagation of some olive (Olea europaea sativa L.) cultivars with difent root-ability, and medium development using analytical data from developing shoots and embryos. Sci. Hort., 24, 123-134.

Snedecore, G.W. and Cochran, W.G. 1989. Statistical methods $\left(8^{\text {th }} \mathrm{Ed}\right)$. The lowa state Univ., Press, Ames, USA. 


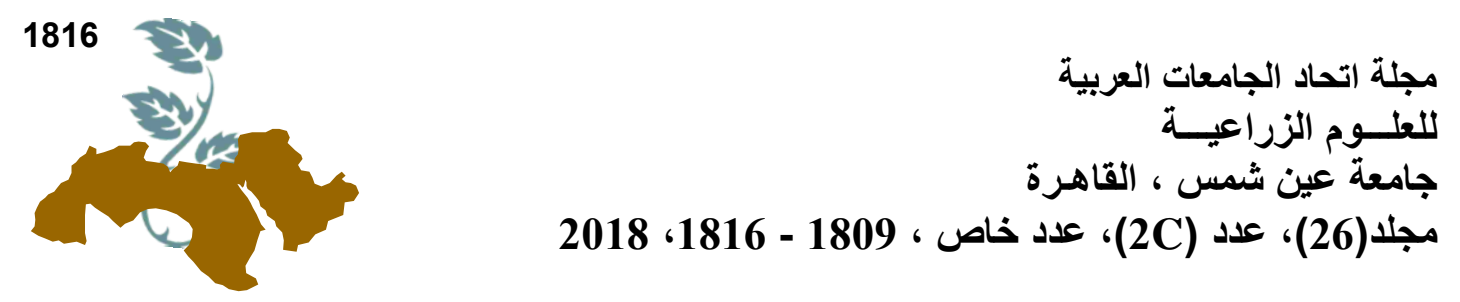

\section{الإكثار المعملي لصنفي الزيتون كروناكى وكوراتينا}

[132]

رحاب نبيل مصطفى 132 - محمد أبورواش على بدر2 ${ }^{2}$ - حسن فاضل الوكيل2 - فرجينى فارس نعمان 132

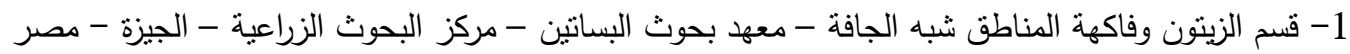

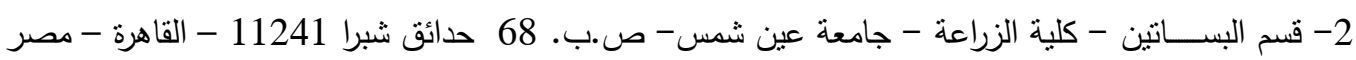

موراثيج وسكوج بأضافة بنزيل أمينو بيورين بتركيز

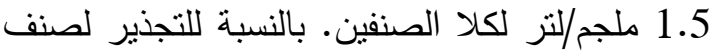

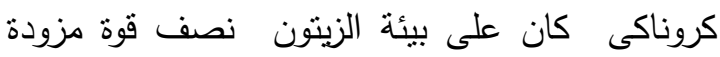

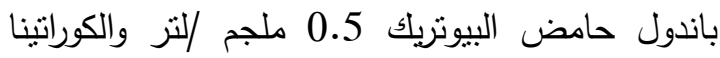

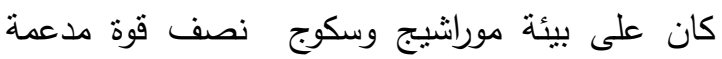
بنفتالين حامض الخليك بتركيز 0.1 ملجم /لتز ومرحلة أقلمة النبيتات لصنف الكروناكى الناتجة من بيئة

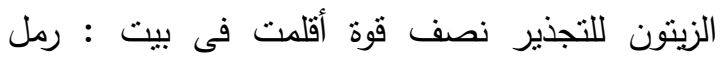

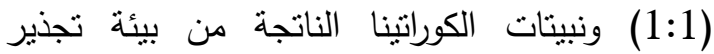

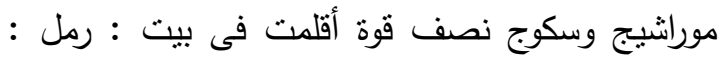
فرميكيولايت (1:1:1).
الكلمات الدالة: الزيتون، كرواتينا، كروناكى، الأكثار المعملى، التعقيم، التضاعف، التجذير، كرواتينا، كروناكي، الأقلمة التحة

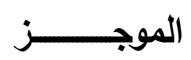

أجريت هذه التجربة فى 2016 للأكثار الدقيق والوصول الى برتوكول مناسب لأكتار صنفى الزيتون كروناكى وكوراتينا كالأتى :تم تعقيم العقد الساقية لتئي بكبريتات النحاس 50 ملجم /لتز لصنف كرونائا كروناكى وأمبيسلين 150 ملجم / لتز لصنف الكات الكوراتينا وكلاهما زرعا على بيئة الزينون. أما التضاعف لـأن كان على بيئة

تحكيم: ا.د إبراهيم محمد دسوقي

ا.د السيــد جمعـه إبراهيم 

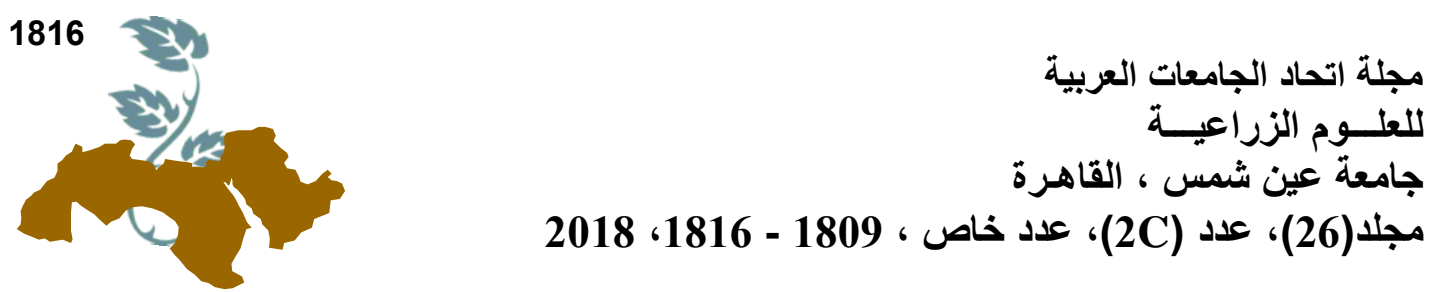

تحكيم: ا.د إبراهيم محمد دسوقي

ا.د السيـــــمعـه إبراهيم 